\title{
Culture et exploitation du palmier-sagoutier dans les Border Montains (Nouvelle-Guinée)
}

Bernard Juillerat

\section{(2) OpenEdition \\ Journals}

Édition électronique

URL : https://journals.openedition.org/tc/1003

DOI : $10.4000 /$ tc. 1003

ISSN : 1952-420X

Éditeur

Éditions de l'EHESS

Édition imprimée

Date de publication : 1 juin 1984

ISSN : 0248-6016

Référence électronique

Bernard Juillerat, «Culture et exploitation du palmier-sagoutier dans les Border Montains (Nouvelle-

Guinée) », Techniques \& Culture [En ligne], 3 | 1984, mis en ligne le 26 janvier 2006, consulté le 29

septembre 2022. URL : http://journals.openedition.org/tc/1003; DOI : https://doi.org/10.4000/tc. 1003

Ce document a été généré automatiquement le 29 septembre 2022.

Tous droits réservés 
Culture et exploitation du palmiersagoutier dans les Border Montains (Nouvelle-Guinée)

Bernard Juillerat 